\title{
The influence of tangible resources and operational performance to promote financial performance of electronic industry
}

\author{
Sasiwimon Wongwilai ${ }^{a^{*}}$, Sarawut Putnuan ${ }^{\mathrm{a}}$, Ananya Banyongpisut ${ }^{\mathrm{a}}$, Watanyu Choopak $^{\mathrm{a}}$, Chatchai \\ Sutikasana $^{\text {b }}$, Kitichai Wongcharoensin ${ }^{\mathrm{c}}$, Metha Oungthong ${ }^{\mathrm{d}}$, Lamphai Trakoonsanti ${ }^{\mathrm{e}}$ and Kittisak \\ Jermsittiparsert ${ }^{\mathrm{f}, \mathrm{g}, \mathrm{h}}$
}

${ }^{a}$ College of Logistics and Supply Chain, Suan Sunandha Rajabhat University, Thailand

${ }^{b}$ Faculty of Business Administration and Information Technology, Rajamangala University of Technology Isan, Thailand

${ }^{c}$ CPL Group Public Company Limited, Thailand

${ }^{d}$ Faculty of Technical Education, King Mongkut's University of Technology North Bangkok, Thailand

${ }^{e}$ Royal Melbourne Institute of Technology University, Australia

${ }^{f}$ Faculty of Administrative, Economic and Social Sciences, University of City Island, Cyprus

${ }^{g}$ Faculty of Social and Political Sciences, Universitas Muhammadiyah Sinjai Indonesia

${ }^{h}$ Faculty of Social and Political Sciences, Universitas Muhammadiyah Makassar, Indonesia

\section{A B S T R A C T}

\section{Article history:}

Received December 1, 2021

Received in revised format

December 15, 2021

Accepted February 22022

Available online

February 22022

Keywords:

Electronic Companies

Tangible Resources

Operational Performance

Supply Chain

Profitability

Sustainable Financial

Performance

\begin{abstract}
The objective of this study is to examine the role of tangible resources and operational performance (OP) in the financial performance (FP). This study examined the relationship between tangible resources, OP, supply chain, profitability and sustainable FP. Furthermore, this study examined the mediation effect of supply chain and profitability. Indonesian electronic companies were selected in the current study for data collection. Therefore, the population is grounded on the Indonesian electronic companies and data were collected from the employees of these companies. 600 questionnaires were used in this study for data collection and 350 questionnaires were returned to analyze the data. Data analysis was carried out through Structural Equation Modeling (SEM). Results of the study highlighted that resources are the major role in FP. Particularly, the tangible resources of the company are vital to enhance the performance in financial terms. Tangible resources have a positive effect on OP, supply chain and profitability. Furthermore, OP has a positive effect on supply chain and profitability which further increases the FP.
\end{abstract}

\section{Introduction}

Financial performance (FP) is the major concern of the companies, as generating revenue is the ultimate objective of every company. It is one of the top priorities of the companies to enhance the performance, particularly, to enhance the FP has major importance. Various companies adopt a number of strategies to increase the FP by considering the importance. Low level of FP can create a number of issues. As the finance is required to promote each and every area of the organization. In case of low FP, companies cannot support various operations to increase the performance of various other areas. For instance, companies require up to date technology to improve the process, services as well as product development stages which require sufficient finance. Moreover, to increase the quality of operations in the organization also requires special people. Experts are required to improve the performance in each area. However, the recruitment of experts in the company also requires finance. Low FP cannot allow the companies to recruit competent staff for the improvement of performance. Therefore, FP is required to improve the various areas of the organization to increase the overall performance and increase the chances of success in the competitive market. Hence, FP has a major role among the organizations (Javed, Rashid, Hussain, \& Ali, 2020; Richardson, Vandenberg, Blum, \& Roman, 2002).

* Corresponding author

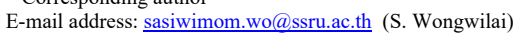

(c) 2022 Growing Science Ltd. All rights reserved.

doi: $10.5267 /$ j.uscm.2022.2.001 
However, the achievement of a significant level of FP is not easy for the companies. It is one of the most crucial tasks for the companies. As all the operations in the company are responsible for FP. To achieve higher performance, the performance of all operations is required. The weakness in one operation may disturb the whole process and cause it to decrease the performance of all the operations. It has a negative effect on the company's overall FP. For instance, the problem in the initial process of product development may influence the whole process of product development. Problems in the operation may increase the overall product cost which causes to increase the price and decrease the FP. Therefore, in an organization, FP has vital importance (Hameed, Waseem, Sabir, \& Dahri, 2020). It is really important for the companies to emphasize on the performance to increase the profitability of the company. Several studies in the literature found that FP is key for the company's success (Hartnell, Karam, Kinicki, \& Dimotakis, 2020; Li et al., 2017). According to the current study, the influence of FP is most critical which leads to the failure of the company in the competitive market. Because in a competitive market, companies require higher performance to further invest and increase the ratio of survival. This could be handled with the help of a number of important strategies to increase the performance. The strategies should be made to enhance the operational performance (OP) of the companies which leads to increase in the overall performance. Strategies to improve all the areas of the organization have a vital role to increase the overall FP. In the case of electronic companies in Indonesia, there are different issues in the performance. These companies are lacking a significant performance level. There is low investment by these companies in the various areas due to which the performance is not high. That is the reason FP is not up to the mark. As the revenue of companies is not much which causes a decrease in the FP. Various countries have a strong network of information technology and a strong electronic industry. That is the reason most of the developed countries are leading the electronic market. For instance, China, India and the United States are leading in information technology due to their strong electronics industry. However, Indonesia is among those countries which are lacking in information technology. The lack of information technology is also due to the low level of electronic companies. The performance of Indonesian electronics companies is quite low as compared to the other developed countries. Therefore, it is really important to increase the FP of these countries. Increase in the FP has a significant effect on the overall electronic industry which leads to increase in the technology. It is important because information technology is one of the most important needs in the current era (AlKhateeb \& Al-Louzi, 2020; Chatterjee, Moody, Lowry, Chakraborty, \& Hardin, 2020). However, the FP of these companies can be increased with the help of various factors. Number of areas of any company is responsible for a better FP. Among all the areas, tangible resources are the major part of FP. Better utilization of resources and proper availability of resources has a positive influence on FP. Better availability of financial resources shows a positive role in supply chain activities. FP is also influenced by the supply chain activities in the organization. Along with this profitability has a major contribution to FP. Furthermore, OP also influences the supply chain and profitability of the companies. Hence, the objective of this study is to examine the role of tangible resources and OP in the FP. Therefore, this study examined the relationship between tangible resources, OP, supply chain, profitability and sustainable FP. Number of previous investigations investigated the role of FP (Gadzo, Kportorgbi, \& Gatsi, 2019; Javed et al., 2020; Mohammed, Flayyih, Mohammed, \& Abbood, 2019), however, these studies have not examined the effect of tangible resources and OP on the FP. Particularly, the effect of tangible resources and $\mathrm{OP}$ is not examined in electronic companies. Moreover, the effect of supply chain and profitability with OP is very rare in the literature among electronic companies.

\section{Literature Review}

FP is the key indicator of company health. Emphasis on different areas of the organization may lead to the better FP (Chetthamrongchai \& Jermsittiparsert, 2019; Pamornmast, Sriyakul, \& Jermsittiparsert, 2019). For instance, resources are the major part of every organization (Altaf, Hameed, Nadeem, \& Arfan, 2019), therefore, the focus of electronic companies on the resources can increase the FP. Majorly, companies should focus on the intangible resources to increase the overall performance (Dampitakse, Kungvantip, Jermsittiparsert, \& Chienwattanasook, 2021). It is one of the most critical parts of the company. It is important because resource management has a crucial role in OP.

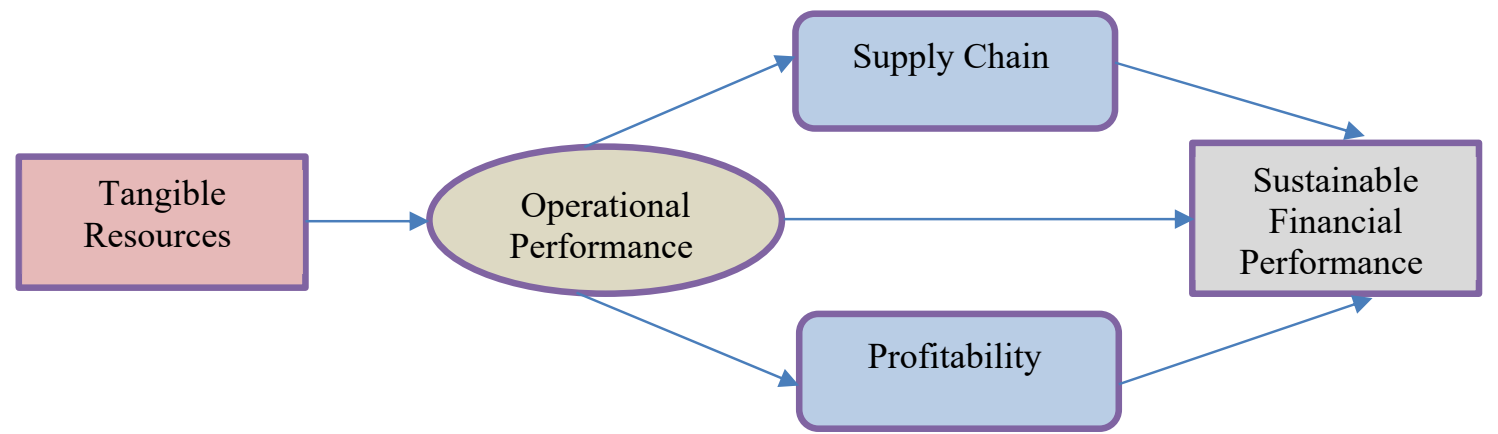

Fig. 1. Theoretical framework of the study showing the relationship between tangible resources, OP, supply chain, profitability and sustainable FP

Positive role of OP leads to the positive effect on the supply chain and profitability of the company. Both supply chain and profitability are the major parts of the companies. It is proved from the number of studies that the supply chain is the most 
key area in number of companies (Ul-Hameed, Mohammad, Shahar, Aljumah, \& Azizan, 2019). Profitability also has a major role in the FP. Furthermore, this study considered the mediating role of supply chain and profitability. Fig. 1 as theoretical framework of the study showing the relationship between tangible resources, OP, supply chain, profitability and sustainable FP.

\subsection{Hypotheses Development}

Tangible resources are basically the physical items such as cash, inventory, various types of machinery, land as well as buildings. These physical items can be easily liquidated as well as have a set value. They are serious in accounting as they assist a company understand its financial standing when arriving on balance sheets as well as financial statements. Tangible resources are the most vital part of business cavities. All the firm's requirements are a minimum amount of tangible resources to carry on the business. It has significant potential to affect the performance of business. As shown in a number of studies, tangible resources are the most vital part of any organization (Corsane, 2017; Pellowski et al., 2017). Tangible resources have a positive role in OP. Generally, better availability of tangible resources has a positive effect on the performance of various operations within the company.

\section{Hypothesis 1. Tangible resources have a positive effect on $O P$.}

OP among a number of companies contributing most significantly to affect the overall performance of the companies. OP has a significant role in the supply chain of the company. OP measures against standard as well as agreed indicators of efficacy, efficiency, as well as environmental responsibility like cycle time, productivity, reduction of waste along with regulatory compliance. In this direction, the effect of OP cannot be neglected as it has a vital role in the organizations. Particularly, the OP among companies has a vital influence on the supply chain. It has a positive role to boost up the FP. As given in previous studies, OP is the most vital part of organizations (Jabbour et al., 2016; Prajogo, Toy, Bhattacharya, Oke, \& Cheng, 2018). Hence, OP has a positive role in FP.

Hypothesis 2. OP has a positive effect on the supply chain.

It is discussed above that OP has an important role in FP because it also has a relationship between profitability. The major concern of each industry shows that it has a major effect on the FP. As the performance is the most critical part of any organization, similarly, it also has a positive role in FP. As the accuracy in the operations of the company shows significant influence on the FP. Because accurate operations of the company are the guarantee to enhance the overall performance. OP in the companies shows a positive effect on the profitability of the company. Increase in the performance of operations increases the profitability. As previous studies show that OP is concerned with the profit of the organization. Operations of the company have significant links with the performance of the company (Talebnia, Salehi, Valipour, \& Shafiee, 2010). As the operations of the firms are the key contributor towards performance (Niu, Park, Yu, \& Kim, 2016).

\section{Hypothesis 3. OP has a positive effect on profitability.}

Previous sections show that OP increases the supply chain activities in the electronic companies. Moreover, it is discussed that OP has a positive role in the profitability of electronic companies. This section shows that the supply chain has a positive role in FP. As supply chain is the major area which shows influence on the FP. Especially, better supply chain in the electronic companies is a major element of timely completion of operations and timely completion of operations finally increases the FP. Supply chain process starts from the manufacturing of products and ends at the delivery to the customer. This whole process of supply chain is majorly linked with FP (Chang, Ellinger, Kim, \& Franke, 2016; Feng et al., 2018).

\section{Hypothesis 4. Supply chain has a positive effect on FP.}

Finally, the FP of electronic companies is also affected by profitability. As profitability is the most key performance element of overall FP. It is always the major objective of the companies which is quite helpful in the FP of the companies. Especially, among the electronic companies, the role of profitability in FP is most important. Increase in the profit of the electronic companies increases the FP. Non-FP is also important; however, FP is most important for the electronic companies of Indonesia because these companies are facing the issues of financial problems. As shown in previous studies, the relationship between FP and profitability (ELENA \& MARIA, 2019; Trumpp \& Guenther, 2017). From the above discussed, it is proved that OP has a positive role in FP. Along with this, the mediating role of supply chain and profitability is also examined which is reflected in below hypotheses;

Hypothesis 5. Profitability has a positive effect on FP.

Hypothesis 6. OP has a positive effect on FP.

Hypothesis 7. Supply chain mediates the relationship between OP and FP.

Hypothesis 8. Profitability mediates the relationship between OP and FP. 


\section{Methodology}

The current study investigated various relationships among the electronic companies of Indonesia. The electronic industry of Indonesia was facing several issues related to the performance. Particularly, the issue of FP has a major role in these companies. Because FP is the vital part of every organization having a significant role in the success. To address these issues, this study examined the relationship between tangible resources, OP, supply chain, profitability and sustainable FP. For this purpose, this study preferred a quantitative research approach to get the final outcomes for the achievement of the study objective (Hamid, Shahid, Hameed, Amin, \& Mehmood, 2019). Hence, this study designed a survey questionnaire to examine the relationship between tangible resources, OP, supply chain, profitability and sustainable FP. Therefore, this study measured the relationship between five variables; tangible resources, OP, supply chain, profitability and FP. All these variables were measured through previous studies. As various scale items for these variables were revealed by the previous studies which were used in the current study. Design of questionnaires was based on two major portions including the profile of respondents and scale items related to the tangible resources, OP, supply chain, profitability and sustainable FP. Indonesian electronic companies were selected in the current study for data collection. Consequently, the population is grounded on the Indonesian electronic companies. Hence, data were collected from the employees of these companies. Total number of 600 questionnaires were used in this study for data collection. From total distributed questionnaires, 350 questionnaires were returned to analyze the data. This data collection process was carried out with the help of simple random sampling (Siuly, Li, \& Wen, 2011) which is most appropriate in the current study for data collection.

\section{Findings}

Findings of the study started with the data screening. Data screening is most essential to deduct the missing value in the data (Aydin \& ŞENOĞLU, 2018). Data screening was also carried out to examine the outlier in the data. Data screening is given in Table 1 showing that data is free from error.

Table 1

Data Statistics

\begin{tabular}{|c|c|c|c|c|c|c|c|c|c|}
\hline & No. & Missing & Mean & Median & Min & Max & SD & Kurtosis & Skewness \\
\hline TR1 & 1 & 0 & 3.556 & 4 & 1 & 5 & 1.12 & -0.308 & -0.581 \\
\hline TR2 & 2 & 0 & 2.929 & 3 & 1 & 5 & 1.165 & -1.662 & -1.344 \\
\hline TR3 & 3 & 0 & 3.474 & 4 & 1 & 5 & 0.923 & -0.52 & -0.65 \\
\hline TR4 & 4 & 0 & 3.436 & 4 & 1 & 5 & 1.306 & -0.828 & -0.504 \\
\hline TR5 & 5 & 0 & 3.368 & 4 & 1 & 5 & 1.289 & -1.933 & -1.44 \\
\hline TR6 & 6 & 0 & 2.991 & 4 & 1 & 5 & 1.325 & -0.942 & -0.477 \\
\hline TR7 & 7 & 0 & 3.496 & 4 & 1 & 5 & 0.999 & -0.646 & -0.481 \\
\hline TR8 & 8 & 0 & 3.549 & 4 & 1 & 5 & 1.173 & -0.407 & -0.586 \\
\hline TR9 & 9 & 0 & 3.669 & 4 & 1 & 5 & 1.302 & -1.649 & -1.729 \\
\hline TR10 & 10 & 0 & 2.911 & 4 & 1 & 5 & 1.272 & -0.884 & -0.48 \\
\hline OP1 & 11 & 0 & 3.504 & 4 & 1 & 6 & 1.358 & -1.057 & -0.372 \\
\hline OP2 & 12 & 0 & 3.526 & 4 & 1 & 5 & 0.999 & -0.583 & -1.632 \\
\hline OP3 & 13 & 0 & 3.489 & 4 & 1 & 5 & 1.186 & -0.779 & -0.396 \\
\hline OP4 & 14 & 0 & 3.368 & 3 & 1 & 6 & 1.229 & -1.617 & -0.245 \\
\hline SUC1 & 15 & 0 & 2.956 & 4 & 1 & 5 & 1.036 & -0.634 & -0.214 \\
\hline SUC2 & 16 & 0 & 3.571 & 3 & 1 & 5 & 0.964 & -0.764 & -1.17 \\
\hline SUC3 & 17 & 0 & 3.459 & 4 & 1 & 5 & 1.198 & -0.454 & -0.604 \\
\hline SUC4 & 18 & 0 & 3.451 & 4 & 1 & 5 & 1.306 & -0.862 & -0.475 \\
\hline PROF1 & 19 & 0 & 2.991 & 4 & 1 & 5 & 1.303 & -1.946 & -0.429 \\
\hline PROF2 & 20 & 0 & 3.511 & 4 & 1 & 5 & 1.212 & -0.684 & -0.476 \\
\hline PROF3 & 21 & 0 & 3.526 & 4 & 1 & 5 & 0.967 & -0.421 & -1.523 \\
\hline PROF4 & 22 & 0 & 3.662 & 4 & 1 & 5 & 1.297 & -0.639 & -0.727 \\
\hline SFP1 & 23 & 0 & 2.996 & 4 & 1 & 5 & 1.272 & -0.836 & -0.512 \\
\hline SFP2 & 24 & 0 & 3.466 & 4 & 1 & 6 & 1.335 & -1.01 & -1.348 \\
\hline SFP3 & 25 & 0 & 3.594 & 4 & 1 & 5 & 1.214 & -1.525 & -0.681 \\
\hline SFP4 & 26 & 0 & 3.947 & 4 & 1 & 5 & 1.028 & 1.177 & -1.152 \\
\hline SFP5 & 27 & 0 & 3.955 & 4 & 1 & 5 & 1.032 & 0.764 & -1.029 \\
\hline
\end{tabular}

Note: TR = Tangible Resources; OP = OP; SUC = Supply Chain; PROF = Profitability; SFP = Sustainable FP

First step of Partial Least Square was carried out by using the PLS algorithms which are recommended in various studies (F. Hair Jr, Sarstedt, Hopkins, \& G. Kuppelwieser, 2014; J. F. Hair, Ringle, \& Sarstedt, 2013; J. F. Hair, Sarstedt, Pieper, \& Ringle, 2012; Hameed, Basheer, Iqbal, Anwar, \& Ahmad, 2018; Henseler et al., 2014). In this process, the factor loadings were examined. It is given in Fig. 2 that tangible resources are measured through 10 scale items. OP was measured through four scale items. Supply chain was measured through four scale items. Profitability was measured through four scale items and finally, sustainable business performance was measured with the help of three scale items. It is given in Table 2 that all the variables; tangible resources, OP, supply chain, profitability and FP have factor loadings above 0.4 which is acceptable to proceed further. 


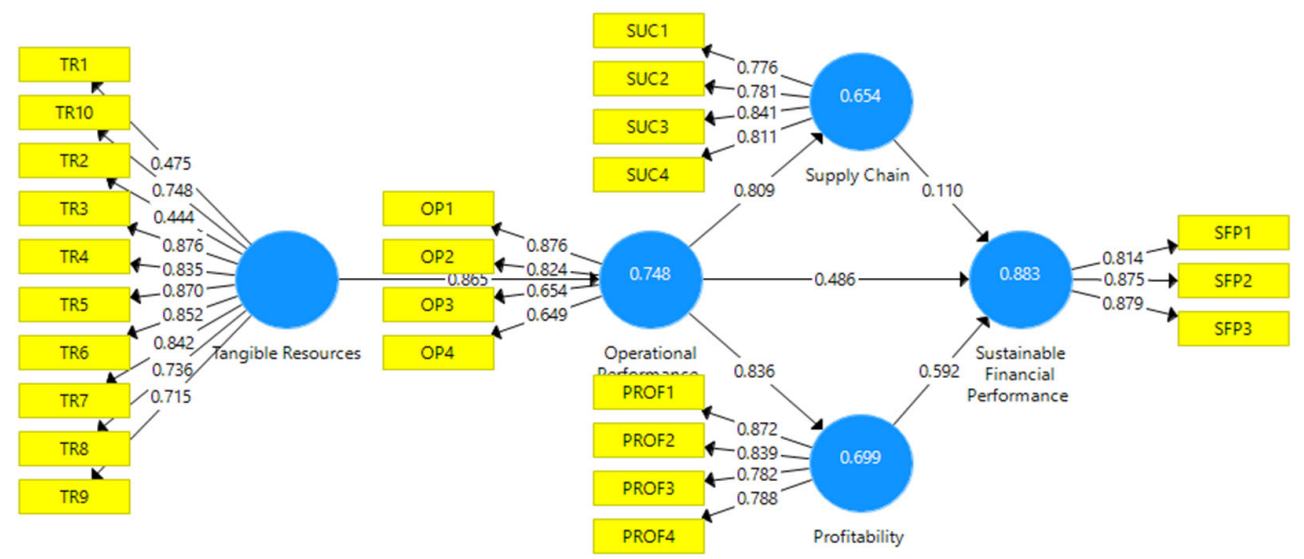

Fig. 2. Measurement Model

Table 2

Factor Loadings

\begin{tabular}{|c|c|c|c|c|c|}
\hline & OP & Profitability & Supply Chain & Sustainable FP & Tangible Resources \\
\hline OP1 & 0.876 & & & & \\
\hline OP2 & 0.824 & & & & \\
\hline OP3 & 0.654 & & & & \\
\hline OP4 & 0.649 & & & & \\
\hline PROF1 & & 0.872 & & & \\
\hline PROF2 & & 0.839 & & & \\
\hline PROF3 & & 0.782 & & & \\
\hline PROF4 & & 0.788 & & & \\
\hline SFP1 & & & 0.814 & & \\
\hline SFP2 & & & 0.875 & & \\
\hline SFP3 & & & 0.879 & & \\
\hline SUC1 & & & & 0.776 & \\
\hline SUC2 & & & & 0.781 & \\
\hline SUC3 & & & & 0.841 & \\
\hline SUC4 & & & & 0.811 & \\
\hline TR1 & & & & & 0.475 \\
\hline TR10 & & & & & 0.748 \\
\hline TR2 & & & & & 0.444 \\
\hline TR3 & & & & & 0.876 \\
\hline TR4 & & & & & 0.835 \\
\hline TR5 & & & & & 0.87 \\
\hline TR6 & & & & & 0.852 \\
\hline TR7 & & & & & 0.842 \\
\hline TR8 & & & & & 0.736 \\
\hline TR9 & & & & & 0.715 \\
\hline
\end{tabular}

Note: TR = Tangible Resources; OP = OP; SUC = Supply Chain; PROF = Profitability; SFP = Sustainable FP

In Table 3, composite reliability (CR) and average variance extracted (AVE) is given. According to J. Hair, Hollingsworth, Randolph, and Chong (2017), CR should not be less than 0.7 and AVE should not be less than 0.5. Table 3 indicated that all the variables; tangible resources, OP, supply chain, profitability and sustainable FP have CR above 0.7 . Moreover, it is found that all the variables; tangible resources, OP, supply chain, profitability and sustainable FP have AVE above 0.5. Thus, all the variables achieved the minimum criteria for CR and AVE. Along with this, the current study also achieved the criteria for discriminant validity (Fornell \& Larcker, 1981) which is examined through cross-loadings as given in Table 4.

Table 3

Reliability and Convergent Validity

\begin{tabular}{|c|c|c|c|c|}
\hline & Alpha & rho_A & CR & AVE \\
\hline OP & 0.763 & 0.818 & 0.841 & 0.574 \\
\hline Profitability & 0.838 & 0.844 & 0.892 & 0.674 \\
\hline Supply Chain & 0.823 & 0.844 & 0.879 & 0.645 \\
\hline Sustainable FP & 0.819 & 0.832 & 0.892 & 0.734 \\
\hline Tangible Resources & 0.909 & 0.924 & 0.927 & 0.569 \\
\hline
\end{tabular}

Note: TR = Tangible Resources; OP = OP; SUC = Supply Chain; PROF = Profitability; SFP = Sustainable FP 
Table 4

Cross-Loadings

\begin{tabular}{|c|c|c|c|c|c|}
\hline & OP & Profitability & Supply Chain & Sustainable FP & Tangible Resources \\
\hline OP1 & 0.876 & 0.798 & 0.715 & 0.869 & 0.799 \\
\hline OP2 & 0.824 & 0.801 & 0.657 & 0.858 & 0.816 \\
\hline OP3 & 0.654 & 0.385 & 0.563 & 0.38 & 0.442 \\
\hline OP4 & 0.649 & 0.378 & 0.493 & 0.393 & 0.417 \\
\hline PROF1 & 0.733 & 0.872 & 0.746 & 0.81 & 0.857 \\
\hline PROF2 & 0.729 & 0.839 & 0.779 & 0.773 & 0.829 \\
\hline PROF3 & 0.645 & 0.782 & 0.619 & 0.69 & 0.692 \\
\hline PROF4 & 0.631 & 0.788 & 0.634 & 0.691 & 0.72 \\
\hline SFP1 & 0.617 & 0.691 & 0.614 & 0.814 & 0.739 \\
\hline SFP2 & 0.846 & 0.818 & 0.719 & 0.875 & 0.793 \\
\hline SFP3 & 0.805 & 0.805 & 0.68 & 0.879 & 0.819 \\
\hline SUC1 & 0.605 & 0.544 & 0.776 & 0.429 & 0.556 \\
\hline SUC2 & 0.563 & 0.53 & 0.781 & 0.409 & 0.535 \\
\hline SUC3 & 0.745 & 0.791 & 0.841 & 0.815 & 0.832 \\
\hline SUC4 & 0.649 & 0.784 & 0.811 & 0.745 & 0.805 \\
\hline TR1 & 0.452 & 0.334 & 0.47 & 0.341 & 0.475 \\
\hline TR10 & 0.638 & 0.692 & 0.588 & 0.825 & 0.748 \\
\hline TR2 & 0.444 & 0.275 & 0.434 & 0.283 & 0.444 \\
\hline TR3 & 0.762 & 0.779 & 0.789 & 0.809 & 0.876 \\
\hline TR4 & 0.682 & 0.79 & 0.803 & 0.748 & 0.835 \\
\hline TR5 & 0.716 & 0.87 & 0.721 & 0.795 & 0.87 \\
\hline TR6 & 0.705 & 0.8 & 0.696 & 0.754 & 0.852 \\
\hline TR7 & 0.724 & 0.822 & 0.772 & 0.763 & 0.842 \\
\hline TR8 & 0.668 & 0.778 & 0.621 & 0.696 & 0.736 \\
\hline TR9 & 0.641 & 0.783 & 0.621 & 0.692 & 0.715 \\
\hline
\end{tabular}

Note: TR = Tangible Resources; OP = OP; SUC = Supply Chain; PROF = Profitability; SFP = Sustainable FP

Nevertheless, this study examined the relationship between variables by using PLS-SEM. The relationship between tangible resources, OP, supply chain, profitability and FP were examined by using the PLS structural model. PLS structural model is highlighted in Figure 4 which is best process of hypotheses testing as given in various studies (Addison et al., 2020; Albassami, Hameed, Naveed, \& Moshfegyan, 2019; Henseler \& Chin, 2010; Henseler \& Fassott, 2010; Henseler, Ringle, \& Sarstedt, 2015; Henseler, Ringle, \& Sinkovics, 2009). The effect of tangible resources was examined on OP. The direct effect of OP was examined on the supply chain. Moreover, the direct effect of OP was examined on profitability. Finally, the direct effect of supply chain and profitability on FP was examined. Results are given in Table 6 showing that tangible resources have a positive effect on OP. Increase in tangible resources increases the FP. Moreover, FP has a positive effect on the supply chain. It is found that OP also has a positive effect on profitability. OP increases the supply chain and profitability of the electronics companies in Indonesia. Moreover, OP has a direct and positive effect on FP. Finally, it is found that supply chain and profitability have a positive effect on FP. Increase in supply chain and profitability, increases the FP.

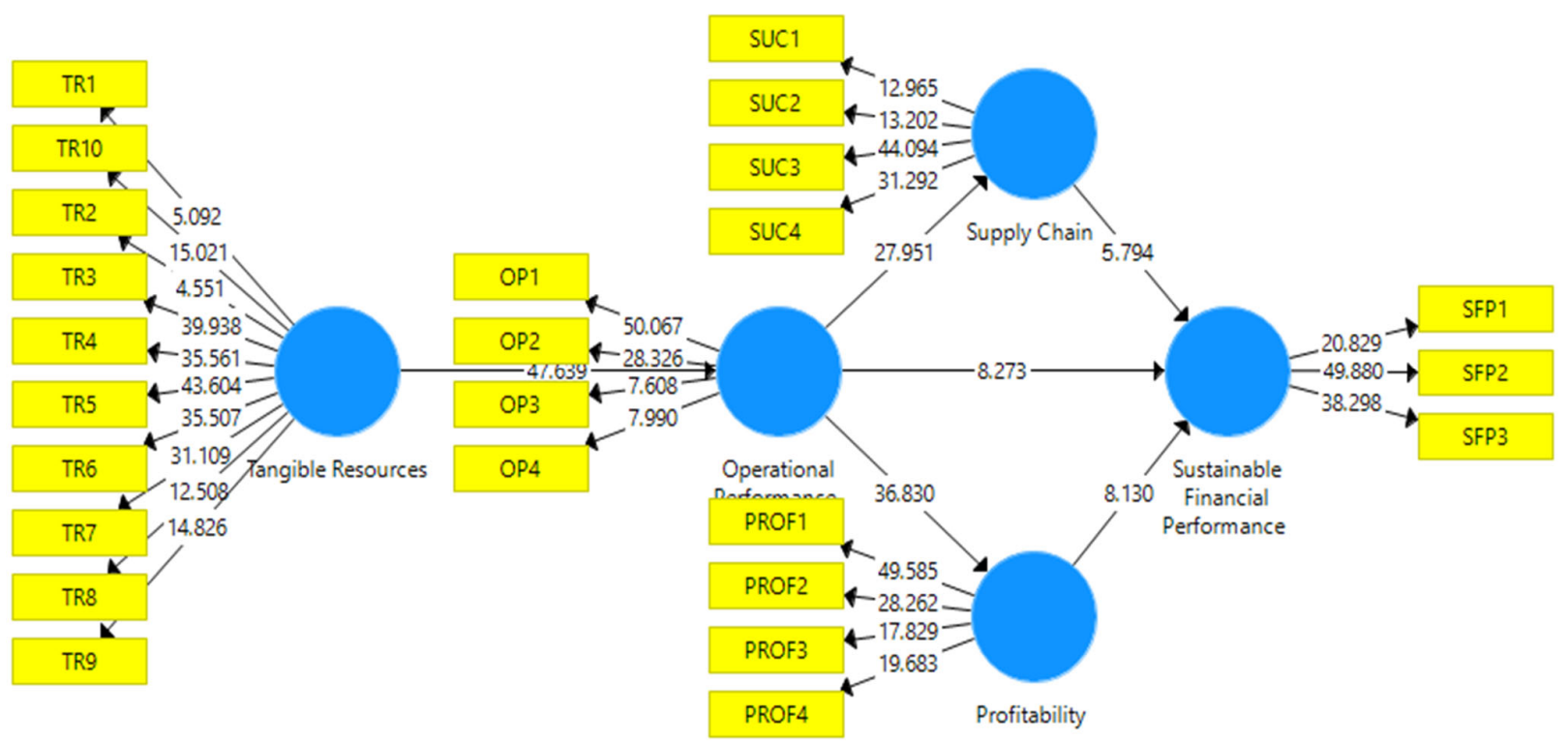

Fig. 4. Structural Model 
Table 5

Direct Effect Results

\begin{tabular}{|c|c|c|c|c|c|}
\hline & $(\mathbf{O})$ & (M) & SD & T Statistics & P Values \\
\hline OP $\rightarrow$ Profitability & 0.836 & 0.84 & 0.023 & 36.83 & 0 \\
\hline OP $\rightarrow$ Supply Chain & 0.809 & 0.811 & 0.029 & 27.951 & 0 \\
\hline $\mathrm{OP} \rightarrow$ Sustainable FP & 0.486 & 0.482 & 0.059 & 8.273 & 0 \\
\hline Profitability $\rightarrow$ Sustainable FP & 0.592 & 0.592 & 0.073 & 8.13 & 0 \\
\hline Supply Chain $\rightarrow$ Sustainable FP & 0.11 & 0.105 & 0.019 & 5.794 & 0.073 \\
\hline Tangible Resources $\rightarrow$ OP & 0.865 & 0.869 & 0.018 & 47.639 & 0 \\
\hline
\end{tabular}

Note: $\mathrm{TR}=$ Tangible Resources; OP = OP; SUC = Supply Chain; PROF = Profitability; SFP = Sustainable FP

After the examination of direct effect, the indirect effect of supply chain and profitability was examined. The indirect effect of the supply chain was examined between OP and FP. The indirect effect of profitability was examined between OP and sustainable FP. Results of the study shows that the indirect effect of supply chain between OP and FP is insignificant with t1.765. The indirect effect of profitability between OP and sustainable FP is significant with t-7.713. Therefore, profitability reflects the positive effect of OP on FP. Results are given in Table 6 . This study also examined the r-square value which is 0.883 for FP. There is strong variance in FP (Chin, 1998). It is indicating that; tangible resources, OP, supply chain and profitability are expected to bring $88.3 \%$ change in FP.

Table 6

Indirect Effect Results

\begin{tabular}{|c|c|c|c|c|c|}
\hline & (O) & (M) & SD & T Statistics & P Values \\
\hline Tangible Resources $\rightarrow$ OP $\rightarrow$ Profitability & 0.723 & 0.731 & 0.032 & 22.842 & 0 \\
\hline Tangible Resources $\rightarrow$ OP $\rightarrow$ Supply Chain & 0.7 & 0.705 & 0.037 & 18.907 & 0 \\
\hline Tangible Resources $\rightarrow$ OP $\rightarrow$ Sustainable FP & 0.421 & 0.419 & 0.05 & 8.445 & 0 \\
\hline $\mathrm{OP} \rightarrow$ Profitability $\rightarrow$ Sustainable FP & 0.495 & 0.498 & 0.069 & 7.173 & 0 \\
\hline Tangible Resources $\rightarrow$ OP $\rightarrow$ Profitability $\rightarrow$ Sustainable FP & 0.428 & 0.434 & 0.064 & 6.692 & 0 \\
\hline OP $\rightarrow$ Supply Chain $\rightarrow$ Sustainable FP & 0.089 & 0.086 & 0.051 & 1.765 & 0.078 \\
\hline Tangible Resources $\rightarrow$ OP $\rightarrow$ Supply Chain $\rightarrow$ Sustainable FP & 0.077 & 0.075 & 0.044 & 1.744 & 0.082 \\
\hline
\end{tabular}

Note: $\mathrm{TR}=$ Tangible Resources; OP = OP; SUC = Supply Chain; PROF = Profitability; SFP = Sustainable FP

\section{Conclusion}

The relationship between tangible resources, OP, supply chain, profitability and sustainable FP was examined in this study to achieve the major objective. The objective of this study was to examine the role of tangible resources and OP in the FP. Furthermore, the indirect effect of supply chain and profitability was also examined. In this study, the pivotal role of tangible resources was found to enhance the OP and FP. Results of the study highlighted that resources are the major role in FP. Without the resources, the electronic companies cannot increase the FP. Particularly, the tangible resources of the company are vital to enhance the performance in financial terms. It is found that tangible resources play a significant role to enhance OP. Increase in the OP increases the supply chain and profitability. Therefore, tangible resources have a positive effect on OP, supply chain and profitability. Additionally, this positive effect of OP on supply chain and profitability increases the FP. Thus, OP has a positive effect on supply chain and profitability which further increases the FP.

\section{References}

Addison, P., McRae, L., Reuter, K., Starkey, M., Milner-Gulland, E., Stephenson, P., . . . Burgass, M. (2020). Bringing sustainability to life: A framework to guide biodiversity indicator development for business performance management. Business Strategy and the Environment.

Al-Khateeb, A., \& Al-Louzi, K. S. (2020). An Exploratory Study on the Impact of Work/Life Balance and Employee Engagement on Talent Management and Organization Performance: A Case of Jordan Telecom and IT Sector. Journal of Social Sciences (COES\&RJ-JSS), 9(3), 617-647.

Albassami, A. M., Hameed, W. U., Naveed, R. T., \& Moshfegyan, M. (2019). Does Knowledge Management Expedite SMEs Performance through Organizational Innovation? An Empirical Evidence from Small and Medium-sized enterprises (SMEs). Pacific Business Review International, 12(1), 11-22.

Altaf, M., Hameed, W., Nadeem, S., \& Arfan, S. (2019). Successful Entrepreneurial Process as Contributor towards Business Performance in Banking: Moderating Role of Passion for Inventing. South Asian Journal of Management Sciences, 13(1).

Aydin, D., \& ŞENOĞLU, B. (2018). ESTIMATING THE MISSING VALUE IN ONE-WAY ANOVA UNDER LONGTAILED SYMMETRIC ERROR DISTRIBUTIONS. Sigma: Journal of Engineering \& Natural Sciences/Mühendislik ve Fen Bilimleri Dergisi, 36(2).

Chang, W., Ellinger, A. E., Kim, K. K., \& Franke, G. R. (2016). Supply chain integration and firm financial performance: A meta-analysis of positional advantage mediation and moderating factors. European Management Journal, $34(3), 282-$ 295. 
Chatterjee, S., Moody, G., Lowry, P. B., Chakraborty, S., \& Hardin, A. (2020). Information Technology and organizational innovation: Harmonious information technology affordance and courage-based actualization. The Journal of Strategic Information Systems, 29(1), 101596.

Chetthamrongchai, P. \& Jermsittiparsert, K. (2019). Impact of Lean Manufacturing Practices on Financial Performance of Pharmaceutical Sector in Thailand. Systematic Reviews in Pharmacy, 10(2), 208-217.

Chin, W. W. (1998). The partial least squares approach to structural equation modeling. Modern methods for business research, 295(2), 295-336.

Corsane, G. (2017). The'turtle'as an illustration of research that equally promotes the use of tangible and intangible heritage resources to safeguard historic buildings: an example of a foreign family's heritage recovered in historic Hankow, China. Paper presented at the Sharing Cultures 2017-5th International Conference on Intangible Heritage.

Dampitakse, K., Kungvantip, V., Jermsittiparsert, K., \& Chienwattanasook, K. (2021). The Impact of Economic Growth, Financial Development, Financial Performance and Capital Growth on the Adoption of Artificial Intelligence in the ASEAN Countries. Journal of Management Information and Decision Sciences, 24(4), 193.

ELENA, V. C., \& MARIA, V. (2019). FINANCIAL PERFORMANCE MEASUREMENT-PROFITABILITY OF INVESTMENT AND ADDED ECONOMIC VALUE. Annals of'Constantin Brancusi'University of Targu-Jiu. Economy Series, 1.

F. Hair Jr, J., Sarstedt, M., Hopkins, L., \& G. Kuppelwieser, V. (2014). Partial least squares structural equation modeling (PLS-SEM) An emerging tool in business research. European Business Review, 26(2), 106-121. doi:https://doi.org/10.1016/j.jfbs.2014.01.002

Feng, M., Yu, W., Wang, X., Wong, C. Y., Xu, M., \& Xiao, Z. (2018). Green supply chain management and financial performance: The mediating roles of operational and environmental performance. Business Strategy and the Environment, 27(7), 811-824.

Fornell, C., \& Larcker, D. F. (1981). Evaluating structural equation models with unobservable variables and measurement error. Journal of marketing research, 18(1), 39-50.

Gadzo, S. G., Kportorgbi, H. K., \& Gatsi, J. G. (2019). Credit risk and operational risk on financial performance of universal banks in Ghana: A partial least squared structural equation model (PLS SEM) approach. Cogent Economics \& Finance, $7(1), 1589406$.

Hair, J., Hollingsworth, C. L., Randolph, A. B., \& Chong, A. Y. L. (2017). An updated and expanded assessment of PLSSEM in information systems research. Industrial Management \& Data Systems, 117(3), $442-458$. doi:https://doi.org/10.1108/IMDS-04-2016-0130

Hair, J. F., Ringle, C. M., \& Sarstedt, M. (2013). Partial least squares structural equation modeling: Rigorous applications, better results and higher acceptance. doi:https://ssrn.com/abstract=2233795

Hair, J. F., Sarstedt, M., Pieper, T. M., \& Ringle, C. M. (2012). The use of partial least squares structural equation modeling in strategic management research: a review of past practices and recommendations for future applications. Long range planning, 45(5-6), 320-340. doi:https://doi.org/10.1016/j.1rp.2012.09.008

Hameed, W. U., Basheer, M. F., Iqbal, J., Anwar, A., \& Ahmad, H. K. (2018). Determinants of Firm's open innovation performance and the role of R \& D department: an empirical evidence from Malaysian SME's. Journal of Global Entrepreneurship Research, 8(1), 29. doi:https://doi.org/10.1186/s40497-018-0112-8

Hameed, W. U., Waseem, M., Sabir, S. A., \& Dahri, A. S. (2020). Effect of enterprise risk management system and implementation problem on financial performance: An empirical evidence from Malaysian listed firms. Abasyn Journal of Social Sciences, 12.

Hamid, S. N. A., Shahid, M. N., Hameed, W. U., Amin, M., \& Mehmood, S. (2019). Antecedents Of Job Stress And Its Impact On Nurse's Job Satisfaction And Turnover Intention In Public And Private Hospitals Of Punjab Pakistan. International Journal of Scientific \& Technology Research, 8(10), 129-137.

Hartnell, C. A., Karam, E. P., Kinicki, A. J., \& Dimotakis, N. (2020). Does Servant Leadership's People Focus Facilitate or Constrain Its Positive Impact on Performance? An Examination of Servant Leadership's Direct, Indirect, and Total Effects on Branch Financial Performance. Group \& Organization Management, 1059601120901619.

Henseler, J., \& Chin, W. W. (2010). A comparison of approaches for the analysis of interaction effects between latent variables using partial least squares path modeling. Structural Equation Modeling, 17(1), 82-109. doi:https://doi.org/10.1080/10705510903439003

Henseler, J., Dijkstra, T. K., Sarstedt, M., Ringle, C. M., Diamantopoulos, A., Straub, D. W., . . Calantone, R. J. (2014). Common beliefs and reality about PLS: Comments on Rönkkö and Evermann (2013). Organizational Research Methods, 17(2), 182-209. doi:https://doi.org/10.1177/1094428114526928

Henseler, J., \& Fassott, G. (2010). Testing moderating effects in PLS path models: An illustration of available procedures Handbook of partial least squares (pp. 713-735): Springer.

Henseler, J., Ringle, C. M., \& Sarstedt, M. (2015). A new criterion for assessing discriminant validity in variance-based structural equation modeling. Journal of the academy of marketing science, 43(1), 115-135. doi:https://doi.org/10.1007/s11747-014-0403-8

Henseler, J., Ringle, C. M., \& Sinkovics, R. R. (2009). The use of partial least squares path modeling in international marketing New challenges to international marketing (pp. 277-319): Emerald Group Publishing Limited. 
Jabbour, C. J. C., de Sousa Jabbour, A. B. L., Govindan, K., De Freitas, T. P., Soubihia, D. F., Kannan, D., \& Latan, H. (2016). Barriers to the adoption of green operational practices at Brazilian companies: effects on green and operational performance. International journal of production research, 54(10), 3042-3058.

Javed, M., Rashid, M. A., Hussain, G., \& Ali, H. Y. (2020). The effects of corporate social responsibility on corporate reputation and firm financial performance: Moderating role of responsible leadership. Corporate Social Responsibility and Environmental Management, 27(3), 1395-1409.

Li, D., Cao, C., Zhang, L., Chen, X., Ren, S., \& Zhao, Y. (2017). Effects of corporate environmental responsibility on financial performance: The moderating role of government regulation and organizational slack. Journal of Cleaner Production, 166, 1323-1334.

Mohammed, B. H., Flayyih, H. H., Mohammed, Y. N., \& Abbood, H. Q. (2019). The effect of audit committee characteristics and firm financial performance: An empirical study of listed companies in Iraq stock exchange. Journal of Engineering and Applied Science, 14(4), 4919-4926.

Niu, S., Park, K., Yu, J., \& Kim, Y. (2016). Operation and performance evaluation of high-speed filter using porous nonwoven filamentous fibre for the treatment of turbid water. Environmental technology, 37(5), 577-589.

Pamornmast, C., Sriyakul, T., \& Jermsittiparsert, K. (2019). Can Lean Manufacturing and 4.0 Industry Enhance the Financial Performance of Pharmaceutical Industries of Thailand? Mediating Role of Waste Reduction Behavior. Systematic Reviews in Pharmacy, 10(2), 318-327.

Pellowski, J. A., Barnett, W., Kuo, C. C., Koen, N., Zar, H. J., \& Stein, D. J. (2017). Investigating tangible and mental resources as predictors of perceived household food insecurity during pregnancy among women in a South African birth cohort study. Social science \& medicine, 187, 76-84.

Prajogo, D., Toy, J., Bhattacharya, A., Oke, A., \& Cheng, T. (2018). The relationships between information management, process management and operational performance: Internal and external contexts. International Journal of Production Economics, 199, 95-103.

Richardson, H. A., Vandenberg, R. J., Blum, T. C., \& Roman, P. M. (2002). Does decentralization make a difference for the organization? An examination of the boundary conditions circumbscribing decentralized decision-making and organizational financial performance. Journal of management, 28(2), 217-244.

Siuly, Li, Y., \& Wen, P. (2011). EEG signal classification based on simple random sampling technique with least square support vector machine. International journal of Biomedical Engineering and Technology, 7(4), 390-409.

Talebnia, G., Salehi, M., Valipour, H., \& Shafiee, S. (2010). Empirical Study of the Relationship between Ownership Structure and Firm Performance: Some Evidence of Listed Companies in Tehran Stock Exchange. Journal of Sustainable Development, 3(2), 264.

Trumpp, C., \& Guenther, T. (2017). Too little or too much? Exploring U-shaped relationships between corporate environmental performance and corporate financial performance. Business Strategy and the Environment, 26(1), 49-68.

Ul-Hameed, W., Mohammad, H., Shahar, H., Aljumah, A., \& Azizan, S. (2019). The effect of integration between audit and leadership on supply chain performance: Evidence from UK based supply chain companies. Uncertain Supply Chain Management, 7(2), 311-328. doi:https://doi.org/10.5267/j.uscm.2018.8.001 
(c)

(C) 2022 by the authors; licensee Growing Science, Canada. This is an open access article distributed under the terms and conditions of the Creative Commons Attribution (CC-BY) license (http://creativecommons.org/licenses/by/4.0/). 